\title{
Maintaining Marriage Behind the Prison: A Qualitative Study Through Incarcerated Husband Perception
}

\author{
Kholifah Umi Sholihah ${ }^{1, *}$, Dian Veronika Sakti Kaloeti ${ }^{2}$, Adi Dinardinata ${ }^{3}$, \\ Laksmi Rahmadian $\mathrm{S}^{4}$ \\ ${ }^{1,4}$ Master of Psychology, Universitas Diponegoro, Semarang, Indonesia \\ ${ }^{2,3}$ Family Empowerment Center, Faculty of Psychology, Universitas Diponegoro, Semarang,Indonesia \\ *Corresponding author. E-mail: kholifahumisholihah@students.undip.ac.id
}

\begin{abstract}
The relationship between husband and wife is an essential thing in marriage. However, there is a special circumstances that have significant effect in marriage, such as imprisonment. The relationship will face many quandaries. This study explores the perception of prisoners toward their marriage and the efforts to maintain the marriage. Using qualitative study and thematic analysis, about 10 incarcerated husband were interviewed used Focus Group Discussion. The results emerged three main themes, namely (1) the negative impacts of imprisonment for family, (2) the challenges of husband-wife relationships and (3) making effort to maintain the husband-wife relationship. Explicitly, marriage commitment, acceptance of the wife, mutual trust, positive communication and support become the strong factors to maintain the marriage behind the prison. Furthermore, the results become important fundamental in developing the rehabilitation program for marriage prisoners and their incarcerated families' community.
\end{abstract}

Keywords: Husband-Wife Relationship, Incarcerated Husband, Qualitative Study.

\section{INTRODUCTION}

Marriage is the important stage in human life, has been proven to make people happier than those who do not have a partner. One of the important things in marriage is a good relationship between husband and wife. This good relationship is an indicator of creating a quality marriage. In addition, the happiness of couples with their marriage relationship, sensitivity and validating couples to each other, skill of communication and conflict management are also factors that affect the quality of marriage [1]. Furthermore, the relationship in marriage is a process that passes through several stages such as effective communication, the process of overcoming the conflict, and contentment in marriage. Other factors that influence are resilience, compatibility, emotional support, and different expectations between husband and wife [1].
The stages in marriage adjustment are important to be understood by couples for dealing with certain situations that have significant effect for the marriage condition, such as the absence of a family member. The absence of a family member for a long time period and due to undesirable reasons absolutely has a significant impact for the family condition, such as a spouse being imprisoned and becoming a prisoner.

In society, prisoners are known to have a negative stigma, because they are suspected or feared that they will commit crimes again. This perception has an impact on the prisoners and their families in their acceptance in society. The process of detention that is carried out can cause various problems and pressures on the prisoners, such as inner conflict, trauma, a tendency to be exclusive, social deviation, suspicion, and anxiety [2]. In addition, mental health problems include anxiety, stress, and depression from mild to severe also pose a threat to the prisoners [3]. Then it is further explained by Sari [4] in which men find it is 
very difficult to overcome the mismatch of social and psychological development that causes negative behavior. The emergence of negative behavior and the impact of the various problems experienced are certainly very influential on the way the couple treats and will lead to problems with the quality of the marriage by the couple.

Based on the various problems that was faced which have been clearly described, the question that arises is how the efforts of the couple to maintain their marriage. Not many research results that discuss this problem, especially from the point of view of the husband who is imprisoned, it encourages researchers to know the description of efforts to maintain a husband-wife relationship when the status of the husband turns into prisoner through the perception of the prisoners themselves.

\section{METHOD}

This research is using a qualitative study. The data will be analyzed using thematic analysis. The data in this study were collected using a Focus group discussion (FGD) which was held in 2 sessions. In the first session, the facilitator conducted FGD with 5 prisoners and 5 other prisoners in the second session. After the FGD is carried out, the data was made into FGD transcripts which were analyzed thematically, making data outlines, building categorization and theme (coordinates and superordinate), evaluating, interpreting the data and drawing conclusions from the data that has been obtained [5].

This research was conducted at Kedungpane prison. The sampling technique was purposive sampling. This technique is used because the sample needed by the researcher has certain characteristics, such as male prisoners, already married, and agreed to join. The number of samples used was 10 male prisoners. The research questions asked to the subject are open-ended questions, so that the subject can express his opinion freely. There are several question points used, which are: (1) the impact of punishment on the family; (2) problems that arise and have an effect on maintaining family integrity; 3) whoever wants and tries to maintain the family integrity.

\section{RESULTS}

Based on the procedures that carried out through thematic analysis, the researchers found three main themes, these are (1) The Impacts of Imprisonment for Family, (2) The Challenges of Husband-Wife Relationships and (3) Making Efforts to Maintain the Husband-Wife Relationship.

\subsection{The Theme of the Impacts of Imprisonment to Family}

\subsubsection{Loss of Trust}

The trust of the wife in her husband begins to disappear because the trusted husband had violated the law until his status changed becomes an inmate.

"The impact on my own family is, first, the trust is definitely disappear, especially from my wife, of course... yes surely mmm... yes, that the matters of finances is not trusted anymore" (S3, FGD1)

\subsubsection{The Inability to Carry Out the Role as the Leader of the Family}

Not being able to maintain the relationship is a consequence of the separation of the inmates from their families, including their wives. The inmates lost their obligation to guide their families.

"The second is, guiding how the household runs so that there is no another party interferes." (S1, FGD2)

\subsubsection{The Wife Replaces the Role of the Husband as the Living Earner}

The imprisonment of the husband makes the wife fills the role of the husband for earning the living to meet the daily needs of the family while the husband is imprisoned.

"My wife still runs a laundry business, but it is not big enough, it is only for life. Then for the needs of school for children, she works very hard. I also feel sorry for it. Yet, I am thankful to God that my wife accepts it. The important thing is the children. My wife is fine as long as the children are not neglected." (S4, FGD1)

\subsubsection{The Family is Being Devastated}

The family becomes so devastated knowing that the subject is in prison. This condition makes the parents become devastated until they are becoming sick, disappointment and stressed.

"My parents are so devastated since I was here" (S5, FGD1)

"My wife was dropped down until she did not want to eat for two weeks. She is stressed for thinking about everything" (S2, FGD1)

\subsubsection{Economic Problems}

This economic problem arises because the husband is imprisoned so he cannot work as usual.

"For me, the impact might be on the economy" (S5, FGD1) 


\subsubsection{The Problems of Children Development}

According to the subject, there are several impacts related to the psychological development of children when the subject is imprisoned and cannot accompany the children as usual.

"After being imprisoned, my child continued to falter. My child is a taekwondo athlete in Central Java. Now, my child never practices again. It is already different. Perhaps because my child is left by me as the father" (S4, FGD1)

\subsubsection{Social Stigma}

According to the subject, they feel that the society sees all the inmate or former inmate as bad people.

"Now we ask, if you know a guy, perhaps he is handsome, successful and so on, but on the way, you can say, he is an ex-inmate, can you still think of oh I still adore you? 80 percent definitely discouraged themselves slowly (...)” (S5, FGD2)

"Our parents-in-laws, if we have entered prison, they think that we must be bad." (S5, FGD1)

\subsection{The Challenges of Husband-Wife Relationship}

\subsubsection{Communication Problems between Couple}

The emergence of communication problems often occurs due to the receipt of inaccurate information which can lead to a fight between married couple.

"If we communicate, we meet, we can talk to each other, right? It will be good. But now, we can only communicate by phone. Sometimes there is a lack of delivery in our communication. There can be miscommunications and it can usually cause us to fight over it." (S3, FGD1)

\subsubsection{Negative Prejudice against Wife}

Negative prejudice or suspicion against the wife is felt by the inmate. According to the inmate, this matter happened because they are separated from their wives, so that sometimes the suspicions arise, leading to fight.

"(...) Even though she does not do it but I am already suspicious. This person (the wife) must be someone like this. Like that." (S2, FGD2)

\subsection{Making Effort to Maintain Husband- Wife Relationship}

\subsubsection{The Existence of Regret and Desire to} Fix the Action

Regret can be identified through the apology from the prisoners to the family at home, which makes them being in trouble.

"Yes, apologizing to the family. Perhaps because we are in prison, they are becoming in trouble. No matter what the reason, we do not know it but we apologize." (S1, FGD2)

"When I get out of here, I want to be a good family leader. What I have experienced in the past, which harmed my family and me, InsyaAllah I will erase it all. We will go to a better path (...) when I come home later, I want to be a good family leader so that my child will not fall into negative things." (S4, FGD1)

\subsubsection{Upholding the Marriage Commitment}

The prisoners think that being married to someone means they have to be ready to be together until the death separates them.

"For me, it is just like the marriage oath that till death we will be apart" (S5, FGD2)

\subsubsection{Mutual Trust}

Even though the prisoners are separated from their wives and other families, with mutual trust in their partners, the efforts to maintain the unity of the family can be done.

"When it comes to matter of the unity of the family, we have to trust each other (...)" (S4, FGD1)

\subsubsection{Mutual Support}

Support is given by the wife to the husband and it's vice versa. The trust from the husband to the wife who has struggled to take care of herself and family even though the husband cannot accompany her.

"We support each other. My wife and I call each other every time, we also support each other anyway. " (S2, FGD1)

\subsubsection{Maintaining Communication between Couple}

According to the prisoners, communication with the partner is important.

"In my opinion, the most important thing is communication." (S2, FGD1) 
"Sometimes by a direct visit, sometimes we communicate through telephone. That is often." (S4, FGD2)

\subsubsection{The Role of the Children}

Children are one of the factors that strengthen the relationship between couple.

"Because our children strengthen us." (S1, FGD2)

\subsubsection{The Existence of Acceptance from the Partner}

Acceptance is important things that must be owned by every couple when someday they faced a condition where the husband's status turns into prisoner.

"Just accept each other (...)" (S2, FGD2)

\subsection{Discussion}

This study found that imprisonment had a very diverse impact on the families of the prisoners. The impact of the imprisonment surely will affect the relationship of husband and wife and the prisoners' families. This is accordance toward the results of research which stated that the experience of imprisonment for someone can cause a higher risk of divorce for prisoners who are married and go to prison [6]. Then, Apel [7] also mentioned that imprisonment can also cause directly and continuously interfere toward household relationship.

The impact of imprisonment that is felt for the incarcerated family is the loss of trust toward their husbands. One of the reasons for this loss of trust is in economic context, where the husband is no longer trusted for earning the living of the family in a proper way. Behavior that violates the law, such as distributing drugs, embezzling money and so on, is done to fulfill the needs of the family to overcome the husband's inability of household needs [8]. This inability affects toward a person to do an illegal act which violates law to the point where the wife's trustworthiness diminished.

The next impact is the inability of husband to cast the role as the leader of the family. This impact is a consequence that directly occurs when a person's status turns into prisoner. The inability of the husband who becomes a prisoner makes the wife inevitably has to replace the husband's role, especially in earning the living for the family. The same efforts and sacrifices were also made by the wives of prisoners in Bongga's [9] study which explained that the subject was enthusiastic and did not give up in earning for her six children, and even the subject wanted to make a business so that the future of her family would be better with her husband once he is free.

Then, another impact that arises in this study is the families become devastated to the point of becoming sick and feel stressed about the fact that their children or husbands have been imprisoned. The devastated of the family members is also found in Noor's [10] study which stated that the shock is experienced by the family because the family knew well the character and the type of the subject's work so far and did not expect the subject to commit crimes and had to be imprisoned. Another challenge that arises when the husband's status turns into a prisoner is dealing to economic problems. It happens absolutely because the husband is the backbone of the family. This condition is also experienced by the wives of the prisoners who have to be the backbone of the family to provide the needs of the family by looking for work so it will not to be trouble for others [9]. This economic challenge and impact are also found by Machdi [11] in the results of his research, which stated that after male prisoners are free, they would prioritize finances and wanted to replace their parents or families who have funded them while in prison.

The challenge was not just about the economy, but the growing of the children also becomes a problem. A father's figure not only has a duty to earn the living, he also has a role in educating children [12]. This is confirmed by the results of research by Hidayati et al [13] which found that the responsibility for parenting between the father and mother is a shared responsibility. Even if the condition of the father and the children is separated by distance, communication through device is not a problem, because of positive emotions, the feeling of pleasure, when communicating can make the father and children relationship became closer [14]. This condition is different from the situation where the status of the father turns into a prisoner where he can not communicate with the children like before. In the results of this study, the child turned into negative path and the lack of father's role could affect the mental condition of the children. It can be happened because the detention of parents can cause children get mental and behavioral health problems [15].

Then, the next is the social stigma problem. The social stigma that appears in this research is that all the prisoners are bad people. The emergence of this social stigma surely will affect the psychological condition of the wives and the children of the prisoners. Moreover, if this negative stigma comes 
from a large family, it is certainly going to weaken the psychological condition of the wives and the children of the prisoners. This social stigma is usually also experienced by the wives, the children oand the families of the prisoners and causes problems in social interaction toward the environment and the appearance of low self-esteem [16]. The social stigma was not only felt when one became prisoner, but also after the prisoners are free, they will also get a negative stigma from society and could lead to difficulties in adapting and socializing with society [17].

Then, another impact of imprisonment on the results of this study is the arise of husband and wife relationship challenges. The challenge of husband and wife relationship. It is the problem of communication between the couple. Communication is a problem that needs to be handled because the more effective interpersonal communication between couple, the more harmonious marriage is, but if communication is not effective, it can also make the marriage risk becomes less harmonious [18]. The existence of distance between the partner whose prisoner husband also creates negative prejudice or suspicion towards the partner because the husband who is imprisoned cannot control and involved in maintaining the unity of the family. Negative prejudice against partner can arise because of communication problems which can be ended up to disappointment and anger [19].

Various problems that arise for the partner who has the status as a prisoner can greatly affect the condition of the marriage relationship. However, besides some challenges faced by the subject and the family, there are efforts made by the subject, wife and family according to the perception of the prisoner that keep family relationships still intact until now. The efforts to maintain the relationship between husband and wife are proven by the presence of regret and the intention of desire to be the better by the husband. This is in line with Cholid [20] where the husband and wife relationship was maintained because of the belief and hope about a better life in the future. This belief, of course, must be accompanied by determination and strength that keep the family together. Beside regret, according to prisoners, the commitment between the two partners, which is very firmly held, is also a factor that keeps the family together. The emergence of commitment as an effort to support the unity of the family is also in line with the results of research by Banurea and Kaloeti [21] which stated that the prisoners' wives preserved their husbands because of marriage commitment. The existence of this commitment is explained by Cho [22] in his research on 369 couples who got results where one's marriage commitment was still maintained because marriage is a form of agreement to God. In addition, this factor becomes important factor because if a person does not have a marriage commitment, divorce will occur in the family [23].

Then, mutual trust and good communication between couple through visits to the prison or via telephone can also strengthen marriage relationship. Yulianti [24] explained that couples who have long-distance relationships will be able to achieve their marriage goals well if the couple maintain mutual trust and have communication. In addition, good communication will also lead to openness between the couple and it is important to maintain the unity of the marriage. This is in accordance with the findings of Miapistia [25] which stated that the relationship that is fostered by openness between partners can minimize the emergence of conflict. Then, the communication between the prisoners and their families through prison visits is also very important because it can make the prisoners more enthusiastic in living their sentences and this family visits, of course, based on the desire to live together and love among all [26]. In this study, it is also explained that family visits can be interpreted as a form of family support for the prisoners. In addition, other forms of support can also be through verbal where the couple encourage each other for surviving. Family or partner support by visiting prison is also an effort to maintain good relationships between families [27].

One of the efforts to maintain the family according to the perception of the prisoners is the factor of children. This is in line with the results of research by Banurea and Kaloeti [21] which stated that children could strengthen resilience in a family's marriage bond. The next factor is acceptance by the partner, where the wife can accept the condition of her husband and be able to wait until the partner is free. Azhar [28] explained that the element of mutual commitment occurs when there is acceptance of each individual's shortcomings. This explains that one of the factors that make a husband and wife relationship intact is the acceptance of the partner.

The efforts made by the couple can strengthen the marriage and maintain the marriage relationship. This effort can also be a protective factor amid the many risk factors faced by couple. Apart from the efforts made by the couple, the risk factors that create a split in a marriage can also make the couple even stronger in maintaining the relationship. This is explained by 
research of Kinanthi [29] which concluded that the presence of risk factors can make couple maintaining their marriage even more. It can be happened because of the partner's ability to interpret positively and have strategies in overcoming the problems at the moment. The way to overcome the problems that have been done is to increasingly seek what can be done to strengthen the unity of the family.

\subsection{Conclusion}

This study reveals the efforts to maintain a couple relationship through the perceptions of male prisoners. In this study, three main themes are found, namely the impact of imprisonment to the family, challenges to husband-wife relationship and the efforts done to maintain husband-wife relationship. The findings of this study indicate that there are many challenges experienced by the assisted residents, including: lost of trust, inability to carry out the role of head of the family, the wife replaces the husband's role as breadwinner, families become devastated, economic problems, child development problems, social stigma, communication problems between spouses and negative prejudice against wives. In addition, efforts were also found to maintain the relationship according to the husband's perception, including: marriage commitment, acceptance of the wife, mutual trust, positive communication and support. All that efforts are the strong factors to maintain the marriage behind the prison. The existence of impacts and efforts done to maintain the unity of the family is important to be known by the prisoners, policy makers and researchers for developing the rehabilitation program for marriage prisoners and their incarcerated families' community.

\subsection{Limitations}

This study has not been able to reveal the interpersonal relationship between husband and wife in most male prisoners because the method used is qualitative. The results of this study also cannot be generalized to prisoners. The next researcher can conduct quantitative research to explore husbandwife relationships so that the results of the study can be generalized to prisoners.

\section{AUTHORS' CONTRIBUTIONS}

KUS and DVSK have analyzed the results and worked on the article. DVSK designed the study, developed the theoretical framework, collected data. AD interviewed participants, and LR wrote the article.

\section{ACKNOWLEDGMENTS}

This research was facilitated under the schema of the International Publication Research (RPI) 2019, Universitas Diponegoro (Grant number: 329-89 / UN7.P4.3 / PP / 2019). We want to express our gratitude to Lembaga Pemasyarakatan Klas 1 Semarang and all incarcerated fathers who share their precious life experiences.

\section{REFERENCES}

[1] A. A. Sutarjo, U. Hasanah, G. D. Artanti. Hubungan antara coping dengan kualitas perkawinan pada ibu rumah tangga, JKKP (Jurnal Kesejaht. Kel. dan Pendidikan). 3(2) (2016) 55-61. DOI: 10.21009/jkkp.032.02.

[2] K. Kartono. Patologi Sosial. Raja Grafindo. 2014.

[3] D. I. Utari, N. Fitria, I. Rafiyah. Gambaran tingkat kecamasan pada warga binaan wanita menjelang bebas di lembaga pemasyarakatan wanita Klas II A Bandung, J. Ilmu Keperawatan, 1(1) (2013) 1-7.

[4] Sari, "Hubungan antara tingkat stres dengan perilaku merokok pada siswa lakilakiperokok smkn 2 Batusangkar. Universitas Andalas, Indonesia. 2011.

[5] V. Clarke, V. Braun.Thematic analysis. J. Posit. Psychol. 12(3) (2017) 297-298. DOI: 10.1080/17439760.2016.1262613.

[6] R. Apel, A. A. J. Blokland, P. Nieuwbeerta, M. van Schellen. The impact of imprisonment on marriage and divorce: A risk set matching approach. J. Quant. Criminol. 26(2) (2010) 269-300. DOI: 10.1007/s10940-009-9087-5.

[7] R. Apel. The effects of jail and prison confinement on cohabitation and marriage. Ann. Am. Acad. Pol. Soc. Sci.665(1) (2016) 103-126. DOI: 10.1177/0002716216629360.

[8] A. P. Dewi, B. Setiawan. Pengaruh ketimpangan pendapatan suami istri terhadap tingginya kasus cerai gugat di pengadilan agama kelas 1b kabupaten Ponorogo. J. Islam. Fam. Law. 3(2) (2019) 119-132.

[9] M. Bongga. Resiliensi pada istri narapidana di kota Balikpapan (Lapas kelas IIA Balikpapan ). Psikoborneo. 5(4) (2017) 812821. 
[10] F. Noor. Intimate relationship pada keluarga narapidana di lapas Sukamiskin Bandung. Universitas Diponegoro, Indonesia. 2016.

[11] R. Machdi. Bagaimana hidup saya setelah ini?. J. Stud. Pemuda. 2(1) (2013) 63-74.

[12] M. Lamb. The role of the father in child development, 5th ed. John Wiley \& Sons Inc. 2010 .

[13] F. Hidayati, D. V. S. Kaloeti, Karyono. Peran ayah dalam pengasuhan anak. Insight J. Ilm. Psikol. 17(2) (2015) 1-10. DOI: 10.26486/psikologi.v17i2.687.

[14] A. Wijayanti. Peran pengasuhan ayah terhadap perkembangan emosi anak. in Seminar Nasional dan Call for Paper Membangun Sinergitas Keluarga dan Sekolah Menuju PAUD Berkualitas, 2018.

[15] S. Wakefield, C. Wildeman. Mass imprisonment and racial disparities in childhood behavioral problems. Criminol. Public Policy. 10(3) (2011) 791-792. DOI: 10.1111/j.1745-9133.2011.00741.x.

[16] R. S. Arimbi. Dampak stigma sebagai 'anak teroris':Studi kasus mengenai tumbuh kembang anak-anak. (2016) 580-596.

[17] Y. Gusef. Adaptasi kehidupan sosial mantan narapidana dalam masyarakat. Andalas. 2011.

[18] N. R. Dewi, H. Sudhana. Hubungan antara komunikasi interpersonal pasutri dengan keharmonisan dalam pernikahan. J. Psikol. Udayana.1(1) (2013) 22-30. DOI: 10.24843/jpu.2013.v01.i01.p03.

[19] A. Rubyasih. Model komunikasi perkawinan jarak jauh. J. Kaji. Komun.4(1) (2016) 109119.

[20] A. Cholid, S. Tono. Pola relasi suami-istri warga binaan di lembaga pemasyarakatan kelas II B Klaten dalam perspektif hukum islam. Universitas Islam Indonesia, Indonesia.2019.

[21] M. Banurea, D. V. S. Kaloeti. Ketangguhan istri warga binaan dengan vonis seumur hidup: Studi fenomenologi deskriptif. Empati. 7(4) (2019) 216-225.

[22] D. W. Cho. The influence of religiosity and adult attachment style on marital satisfaction among Korean Christian couples living in
South Korea. Liberty University, Virginia. 2014.

[23] B. Prianto, N. W. Wulandari, A. Rahmawati. Rendahnya komitmen dalam perkawinan sebagai sebab perceraian. Komunitas Int. J. Indones. Soc. Cult..5(2) (2014) 208-218. DOI: 10.15294/komunitas.v5i2.2739.

[24] A. Yulianti. Emosional distress dan kepercayaan terhadap pasangan yang menjalani commuter marriage. Semin. Psikol. Kemanusian (2015) 978-979.

[25] G. Miapistia. Relationship maintenance dalam commited romantic relationship pasangan suami istri yang menjalani commuter marriage. E-Komunikasi. 5(1) (2017) 1-10.

[26] Faricin. Urgensi kunjungan keluarga dalam meningkatkan kesehatan mental warga binaan di lembaga pemasyarakatan kelas 1 Kedungpane Semarang. UIN Walisongo, Indonesia. 2017.

[27] I. Lander. Towards the incorporation of forgiveness therapy in healing the complex trauma of parental incarceration. Child Adolesc. Soc. Work J.29(1) (2012) 1-19. DOI: $10.1007 / \mathrm{s} 10560-011-0248-7$.

[28] Azhar. Peranan daya tarik fisik terhadap perasaan cinta pada lelaki yang memiliki wanita dengan tunanetra. Ejournal Psikol. 2(1) (2013) 92-99.

[29] M. R. Kinanthi. Faktor penentu komitmen pernikahan pada kelompok populasi tahap pernikahan transition to parenthood hingga family with teenagers. Psikodimensia. 17(1) (2018) 63-76.

DOI: 10.24167/psidim.v17i1.1504. 